\title{
RASIONALISASI EKONOMI POLITIK LINGKUNGAN DALAM EU-JAPAN ECONOMIC PARTNERSHIP AGREEMENT (EU-JEPA)
}

\author{
Rafsyanjani Mohammad \\ Program Studi Magister Hubungan Internasional, Universitas Airlangga, Indonesia; \\ rafsyanjani.mohammad-2019@fisip.unair.ac.id
}

\begin{abstract}
This paper explained the rationale behind the inclusion of the "Paris Agreement clause" by EU in the EU-Japan Economic Partnership Agreement (EU-JEPA) which has been in force since 2019. Furthermore, this paper would analyze environmental political economy and diplomacy factors that became determinants of the inclusion. To study this circumstance, the author used environmental political economy institutionalist perspective and environmental diplomacy concept especially regarding compliance issue within it. The adopted method is qualitative through a literature study from both primary and secondary sources. Based on these theoretical backgrounds, the author argued that the inclusion is motivated by EU's economic and environmental regional politics interests. Moreover, when viewed from environmental diplomacy aspects, the inclusion is also caused by EU's interest to strengthen compliance within Paris Agreement regime and at the same time protect it from existential threats provoked by US's departure.
\end{abstract}

Keywords: environmental political economy, EU-JEPA, European Union, Paris Agreement

\begin{abstract}
Abstrak
Penelitian ini membahas rasionalisasi dimasukkannya klausul kepatuhan Paris Agreement oleh Uni Eropa ke dalam EU-Japan Economic Partnership Agreement (EU-JEPA) yang telah berlaku sejak 2019 lalu. Penelitian akan dilakukan dengan meninjau faktor ekonomi politik dan diplomasi lingkungan yang dipandang merupakan determinan dari kebijakan tersebut. Guna menjawab permasalahan di atas, penulis menggunakan perspektif ekonomi politik lingkungan institusionalisme dan konsep diplomasi lingkungan terkhusus menyangkut isu kepatuhan di dalamnya. Metode yang digunakan adalah metode penelitian kualitatif melalui studi pustaka baik dari sumber primer maupun sekunder. Berdasarkan landasan pemikiran ini penulis berpendapat bahwa pengambilan kebijakan ini dilatarbelakangi oleh adanya faktor kepentingan ekonomis dan politik domestik lingkungan Uni Eropa. Selain itu, apabila ditinjau dari aspek diplomasi lingkungan maka kebijakan ini juga disebabkan oleh kepentingan Uni Eropa untuk memperkuat kepatuhan akan rezim Paris Agreement dan sekaligus melindunginya dari ancaman eksistensi yang diakibatkan oleh keluarnya Amerika Serikat.
\end{abstract}

Kata Kunci: ekonomi politik lingkungan, EU-JEPA, Paris Agreement, Uni Eropa 


\section{Pendahuluan}

Proses integrasi global, atau globalisasi ekonomi, yang terjadi sejak hampir 60 tahun silam telah berdampak signifikan pada pertumbuhan perdagangan antarnegara. Sebagai salah satu motor perkembangan ekonomi, perdagangan internasional terus digalakan agar semakin berjalan bebas dan tidak menemui berbagai hambatan. Proses liberalisasi ini berdampak pada meningkatnya nilai dan volume perdagangan internasional pada abad ini. Data Bank Dunia menunjukkan bahwa nilai ekspor barang dan jasa global pada tahun 2019 telah mencapai angka US\$ 24,795 triliun atau tumbuh drastis dari angka US\$ 383,603 milyar pada tahun 1970 (World Bank, 2019a). Selain mengalami pertumbuhan drastis dari segi valuasinya, perdagangan internasional juga semakin memperlihatkan pengaruhnya terhadap perkembangan ekonomi global. Data Bank Dunia kembali menunjukkan bahwa pada tahun 2019 proporsi perdagangan global terhadap pendapatan domestik bruto (PDB) global hampir mencapai 60,4 persen atau tumbuh drastis dari 27,3 persen pada tahun 1970 (World Bank, 2019c). Kontribusi perdagangan yang cukup besar ini turut berakibat pada semakin "sejahteranya" dunia yang dapat dilihat dari nominal PDB global pada tahun 2019 yang mencapai US\$ 87,698 triliun atau meningkat secara pesat dari US\$ 2,961 triliun pada tahun 1970 (World Bank, 2019b).

Ketika perdagangan internasional menunjukkan perkembangannya yang masif, diskursus mengenai hubungan antara perdagangan dan lingkungan mulai menjadi topik yang hangat diperbincangkan. Di dalam buku mereka "Paths to a Green World: The Political Economy of the Global Environment", Clapp dan Dauvergne (2005) menyatakan bahwa setidaknya terdapat empat perspektif utama yang berkembang dalam diskursus mengenai perubahan lingkungan global dan hubungannya dengan ekonomi politik global, yakni perspektif liberalis pasar (market liberals), institusionalis, bioenvironmentalis, dan sosialis hijau (social greens).

Clapp (2014) berpendapat dalam tulisannya yang berjudul "International Political Economy and the Environment" bahwa telah terjadi perdebatan panas yang panjang antara pihak yang mendukung perdagangan bebas dan pihak yang menentangnya. Para pendukung perdagangan bebas (liberalis pasar) berpandangan bahwa secara keseluruhan perdagangan berdampak positif bagi lingkungan. Argumentasi utama mereka terletak pada faktor efisiensi dan konservasi dari perdagangan bebas di mana dengan menerapkan kebijakan spesialisasi produksi, maka negara dapat mengalokasikan sumber daya langka mereka lebih efisien apabila dibandingkan dengan negara proteksionis yang menerapkan strategi self suffiency. Berbeda dengan pandangan kaum 
pendukung, kalangan penentang (bioenvironmentalis dan sosialis hijau) justru beranggapan bahwa liberalisasi perdagangan global telah berdampak negatif terhadap lingkungan. Mereka beranggapan bahwa justru liberalisasi perdagangan semakin mendorong negara-negara (terutama negara berkembang) di dunia untuk semakin meningkatkan output industri mereka yang sering kali berakibat pada rusaknya lingkungan seperti penggundulan hutan, penambangan berlebih, dan penumpukan limbah industri yang berbahaya.

Perdebatan kedua perspektif tersebut terus berlanjut hingga munculnya isu perubahan iklim di dalam diskursus rezim lingkungan global. Berbagai inisiatif terkait isu ini telah dilakukan oleh rezim global yang utamanya dikomandoi oleh Perserikatan Bangsa-Bangsa (PBB), termasuk salah satunya dalam bentuk tercapainya kesepakatan Paris Agreement mengenai perubahan iklim. Kesepakatan ini merupakan kesepakatan internasional di bawah United Nations Framework Convention on Climate Change (UNFCC) yang tercapai saat diadakannya (COP) 21 di Paris pada tahun 2015. Tujuan utama dari Paris Agreement adalah memperkuat respons global terhadap ancaman perubahan iklim dengan menjaga kenaikan suhu global pada abad ini di bawah $2{ }^{\circ} \mathrm{C}$, di atas tingkat masa pra-industri, dan untuk mengejar upaya membatasi kenaikan suhu lebih jauh hingga $1,5^{\circ} \mathrm{C}$ (United Nations Framework Convention on Climate Change, 2019). Uni Eropa telah berpartisipasi secara aktif dalam Paris Agreement, mulai dari proses negosiasi hingga pada implementasi dari kesepakatan tersebut.

Diskursus mengenai hubungan antara perdagangan dan lingkungan mulai memasuki dimensi baru tatkala Uni Eropa mengambil kebijakan untuk tidak mengadakan kesepakatan dagang dengan pihak yang tidak ikut serta dalam perjanjian lingkungan internasional Paris Agreement, serta pihak yang tidak mengambil langkah konkret dalam memerangi pemanasan global. Pada tahun 2018 Uni Eropa melalui Komisioner Perdagangan Cecilia Malmström menyatakan bahwa referensi akan Paris Agreement merupakan hal yang dibutuhkan dalam kesepakatan dagang Uni Eropa (Stone, 2018). Arah kebijakan perdagangan Uni Eropa yang turut mengikutsertakan klausul Paris Agreement ini diimplementasikan pertama kali dalam EU-Japan Economic Partnership Agreement (EU-JEPA) yang disepakati oleh kedua belah pihak pada 17 Juli 2018 dan berlaku sejak 1 Februari 2019. Klausul kepatuhan Paris Agreement lebih spesifik termaktub dalam bab Trade and Sustainable Development Pasal 16.4. Selain merupakan sesuatu yang pertama kali diinisiasi oleh Uni Eropa, EU-JEPA juga merupakan perjanjian dagang bilateral pertama di dunia yang memasukkan klausul kepatuhan Paris Agreement ke dalam ketentuan-ketentuannya. 
Klausul (lingkungan) Paris Agreement dalam kesepakatan (perdagangan bebas) EU-JEPA ini sangat jelas berlawanan dengan apa yang digaungkan oleh dua perspektif sebelumnya. Perspektif pro-perdagangan menggalakkan ketidakperluan adanya hambatan-hambatan lingkungan dalam berbagai kesepakatan dagang mengingat peran positif dari perdagangan itu sendiri. Sebaliknya, perspektif kontra-perdagangan mengampanyekan pelambatan atau bahkan pemberhentian segala bentuk perjanjian yang mempromosikan perdagangan bebas. Tidak adanya kesepakatan diantara dua paradigma ini terjadi seiring dengan perbedaan diantara keduanya dalam memahami relasi antara perdagangan dan lingkungan. Lantas, bagaimana kehadiran klausul Paris Agreement dalam EU-JEPA ini dapat dijelaskan rasionalisasinya?

\section{Rasionalisasi Ekonomi, Perspektif Institusionalis, dan Diplomasi Lingkungan}

\section{Rasionalisasi Ekonomi}

Dalam memahami rasionalisasi ekonomi politik lingkungan dari kebijakan Uni Eropa yang memasukkan klausul kepatuhan Paris Agreement di dalam EU-JEPA, terdapat beberapa tulisan sejenis yang telah berusaha menjelaskan faktor-faktor tersebut. Penulis membaginya ke dalam dua kategori. Kategori pertama, tulisan yang mengemukakan pertimbangan keuntungan ekonomis sebagai rasionalisasi negara untuk berkecimpung dalam agenda lingkungan pada kesepakatan dagang. Kategori kedua, riset yang menyertakan aspek pengaruh politik domestik.

Penelitian Foramitti (2019) menjelaskan bahwa keinginan Uni Eropa untuk memasukkan bab Trade and Sustainable Development (TSD) adalah adanya potensi keuntungan ekonomis. Argumen ini juga didukung oleh Becker (2019) yang menyebutkan bahwa kepentingan ekonomis menjadi faktor pendorong bagi negara dalam menerapkan standar lingkungan yang sesuai dengan kesepakatan internasional. Milewicz dkk (2018) menambahkan bahwa kesediaan negara tersebut juga dipengaruhi oleh prospek kemunculan berbagai perjanjian dagang ke depannya yang turut membawa klausul lingkungan. Negara tentu tidak ingin tertinggal dari potensi keuntungan yang didapatnya dari perjanjian-perjanjian tersebut. Hal inilah yang sering kali pula negosiasi klasul lingkungan dalam kesepakatan dagang berjalan alot karena adanya pertentangan kepentingan ekonomi yang kuat seperti yang diutarakan oleh Morin dan Jinnah (2018). 
Selain rasionalisasi ekonomis, negara juga bertindak atas dasar kondisi dan struktur politik domestiknya. Moltke (2002), Werksman dan Buri (2019), dan Nakanishi (2020) mengemukakan bahwa penyertaan klausul lingkungan di dalam perjanjian dagang Uni Eropa dimaksudkan untuk mengakomodasi iklim regulasi dan struktur politik yang ada di Uni Eropa itu sendiri. Olper (2016) menambahkan signifikansi peran civil society dalam kapasitasnya sebagai voters dan lobbying groups yang mampu mempengaruhi perilaku pemerintah termasuk mengenai agenda lingkungan dalam kesepakatan dagang.

Tinjauan penulis atas tulisan-tulisan di atas memperlihatkan bahwa keinginan negara untuk memasukkan agenda lingkungan ke dalam kesepakatan dagang dipengaruhi oleh berbagai faktor, di antaranya dapat berupa faktor ekonomis atau politik domestik. Dalam penelitian ini penulis menempatkan diri pada argumen bahwa semua faktor tersebut memiliki pengaruhnya masingmasing di dalam kasus EU-JEPA. Namun, di samping dua faktor tersebut penulis turut melihat peran penting faktor kondisi rezim internasional serta partisipasi negara dalam tatanan tersebut. Dalam tulisan ini, faktor tersebut tercermin dalam kondisi Paris Agreement yang pada saat itu (dan hingga kini) terancam legitimasinya dengan keluarnya Amerika Serikat. Oleh karena itu, penulis akan turut membahas faktor ini sebagai salah satu faktor yang mempengaruhi adanya klausul Paris Agreement di dalam EU-JEPA.

Berdasarkan pembahasan di atas, tulisan ini akan diarahkan untuk menjawab pertanyaan penelitian yang menanyakan tentang keterkaitan rasionalisasi ekonomi politik lingkungan antara kesepakatan dagang dengan langkah-langkah lingkungan (environmental measures). Secara khusus tulisan ini berangkat dari rumusan masalah yakni, "Mengapa Uni Eropa memasukkan klausul kepatuhan Paris Agreement ke dalam kesepakatan dagangnya dengan Jepang dalam bentuk EU-JEPA?". Penulis berargumen bahwa faktor rasionalisi ekonomi politik lingkungan telah berpengaruh pada dimasukkannya klausul kepatuhan Paris Agreement oleh Uni Eropa dalam EUJEPA.

\section{Perspektif Institusionalis}

Seperti yang telah dibahas bahwa terdapat dua spektrum perspektif dalam studi Ekonomi Politik Internasional (EPI) yang saling bertolak belakang dalam melihat keterkaitan antara perdagangan dan lingkungan. Namun, berbeda dengan dua kubu tersebut, perspektif institusionalis hadir untuk 
mengakomodasi dan menjembatani argumentasi masing-masing kubu. Perspektif inilah yang akan digunakan oleh penulis untuk menjawab pertanyaan penelitian sebelumnya.

Perspektif institusionalis memberikan analisis diagnostic bahwa pada prinsipnya hubungan antara perdagangan dan lingkungan bersifat positif. Perspektif institusionalis berbagi pandangan yang sama dengan kubu pendukung mengenai dampak positif dari perdagangan, investasi, dan liberalisasi pasar terhadap lingkungan. Namun, hubungan positif tersebut hanya bisa dicapai apabila terdapat pembatasan-pembatasan di dalamnya. Perspektif institusionalis menyadari bahwa terdapat beberapa bentuk perdagangan yang tidak boleh didukung oleh rezim perdagangan global akibat dampaknya yang berbahaya bagi lingkungan seperti perdagangan zat beracun dan zat kimia berbahaya. Selain itu, pembatasan ini perlu dilakukan untuk mengakomodasi potensi adanya kerusakan lingkungan yang sering ditimbulkan oleh motif ekonomi negara. Guna meraup dampak positif baik dalam hal perdagangan dan lingkungan semaksimal mungkin, perspektif institusionalis memberikan analisis prognostic yakni dimasukkannya trade measures ke dalam kesepakatankesepakatan lingkungan dan sebaliknya, environmental measures menjadi salah satu bagian dalam bentuk perjanjian-perjanjian dagang antarnegara (Clapp, 2014).

Berdasarkan analisis diagnostic dan prognostic yang diajukan oleh perspektif institusionalis maka dapat ditarik pula proposisi mengenai rasionalisasi negara dalam memasukkan klausul lingkungan ke dalam perjanjian dagangnya. Dengan memasukkan klausul tersebut maka negara dapat meraup dampak berimbang yang bernilai positif baik dalam usaha pengembangan kesejahteraan ekonomi maupun perlindungan lingkungan. Dampak positif inilah yang menjadi rasionalisasi negara dalam memasukkan klasul lingkungan.

Konsepsi perspektif ekonomi politik lingkungan institusionalisme dalam tulisan ini dimaknai sebagai adanya rasionalisasi ekonomi politik lingkungan yang mendasari kebijakan Uni Eropa dalam memasukkan klasul kepatuhan Paris Agreement ke dalam EU-JEPA. Motif ekonomi politik lingkungan di sini terepresentasi dalam bentuk kepentingan ekonomis dan kepentingan politik lingkungan domestik. Kepentingan ekonomis di sini berupa 1) Semakin meningkatnya kompetitivitas domestik seiring dengan berkurangnya praktik race to the bottom di antara partner dagang dan 2) Sebagai proyeksi keinginan Uni Eropa untuk menjadi pemimpin ekonomi global alternatif di tengah proteksionisme China dan Amerika Serikat. Kepentingan politik lingkungan domestik di sini berupa terealisasikannya norma dan prinsip kebijakan lingkungan regional Uni Eropa pada tingkat internasional. 


\section{Diplomasi Lingkungan}

Selain didorong oleh keuntungan ekonomis dan politik lingkungan domestik, rasionalisasi kebijakan Uni Eropa ini juga ternyata turut dipengaruhi oleh realita tata kelola lingkungan global. Oleh karena itu, tulisan ini juga akan menggunakan konsepsi diplomasi lingkungan sebagai landasan pemikirannya. Diplomasi lingkungan dapat didefinisikan sebagai "The established method of international discourse or the art of managing international relations, chiefly by negotiation, on issues related to environment" (Pisupati, 2015).

Diplomasi lingkungan pada awalnya hanya berkutat pada isu-isu lokal dan dilakukan diantara aktor negara dalam jumlah yang terbatas. Hingga awal 1970-an tema utama diskursus lingkungan global berpusat pada isu transboundary pollution dan resources scarcities (Stevis, 2014). Perhatian akan isu-isu tersebut pun pada umumnya datang dari negara-negara maju yang mulai merasakan dampak negatif dari masifnya proses industrialisasi di negara-negara mereka. Oleh karena itu, Multilateral Environmental Agreements (MEAs) yang dihasilkan pada periode ini juga sebagian besar merupakan hasil inisiasi negara-negara maju yang ditujukan untuk mengatasi permasalahan polusi industri dan konservasi alam lintas batas diantara mereka sendiri.

Namun, seiring dengan meningkatnya bukti ilmiah tentang kehadiran perubahan iklim, diplomasi lingkungan juga dipaksa untuk berubah. Bahaya global yang ditimbulkan oleh perubahan iklim menjadi alarm pembangun bagi negara-negara di dunia bahwa kerja sama lingkungan yang lebih komprehensif menjadi suatu keniscayaan. Semua pihak baik negara maju maupun berkembang, negara kuat atau lemah, negara banyak atau sedikit penduduk harus turut berkontribusi dalam menghadapi masalah "keplanetan" bersama ini. Sekiranya terdapat lima elemen utama yang menggambarkan diplomasi lingkungan yakni 1) Subjek permasalahan (perubahan iklim) lebih bersifat jangka panjang, 2) Pentingnya peran ilmu pengetahuan dan ilmuwan, 3) Kompleksitas negosiasi yang melibatkan banyak pihak, 4) Keterlibatan isu kesetaraan dan 5) Menggunakan pendekatan diplomatis yang kreatif dan non-konvensional (Benedick, 1998).

Terlepas dari meningkatnya skala diplomasi yang tercermin dari semakin banyaknya MEAs, diplomasi lingkungan masih terjerat dalam problema kepatuhan (compliance). Secara teoretis, kepatuhan dalam perjanjian internasional dapat dipromosikan baik melalui insentif positif (wortel) seperti bantuan pendanaan maupun insentif negatif (tongkat) seperti sanksi dan embargo (Kolari, 2002). MEAs menjadi bermasalah karena pada umumnya tidak memiliki wortel yang cukup lezat 
dan tongkat yang cukup keras untuk mendorong kepatuhan negara-negara. Hal ini terjadi karena sejak perumusannya, MEAs didesain sangat fleksibel guna disepakati oleh seluruh kalangan.

Salah satu cara guna meningkatkan masalah kepatuhan dalam diplomasi lingkungan adalah melalui issue-linkages. Issue-linkages di sini dipahami sebagai fungsi dimana diplomasi lingkungan yang lebih lemah dapat meminjam kekuatan enforcement yang dimiliki oleh bentuk diplomasi lain yang lebih kuat seperti ekonomi (Jinnah, 2011). Diplomasi ekonomi perdagangan seperti dalam bentuk Free Trade Agreements (FTAs) yang bersifat lebih kuat karena memiliki aspek legalisasi (kewajiban, ketepatan, dan delegasi) yang komprehensif dan keras (Condon, 2015). Issue-linkages dilakukan dengan cara memasukkan norma perlindungan lingkungan atau bahkan kepatuhan sebuah MEAs sebagai salah satu klausul di dalam FTAs.

Konsepsi diplomasi lingkungan di sini dipahami sebagai adanya rasionalisasi tambahan berupa kepentingan untuk menjaga keberlangsungan tata kelola lingkungan. Uni Eropa memasukkan klausul kepatuhan Paris Agreement ke dalam prasayarat FTAs-nya (termasuk EUJEPA) sebagai cara untuk meningkatkan kepatuhan rezim lingkungan melalui kekuatan enforcement yang ditawarkan oleh FTAs tersebut. Sebagai salah satu aktor terdepan dalam diplomasi lingkungan Uni Eropa memandang bahwa efektivitas Paris Agreement juga menjadi salah satu kepentingan luar negerinya. Kepentingan ini dipandang semakin urgen tatkala keluarnya AS dari rezim Paris Agreement yang menghadirkan ancaman besar terhadap keberlangsungan rezim perubahan iklim tersebut.

\section{Metode}

Guna menjelaskan fenomena dimasukkannya klausul Paris Agreement oleh Uni Eropa dalam EUJEPA, maka penulis menggunakan metode penelitian kualitatif. Metode ini menekankan pada pengumpulan dan telaah data nonnumerik dari suatu fenomena untuk mencari tahu penjabaran dibaliknya. Penggunaan metode ini mensyaratkan adanya pengumpulan data-data kualitatif baik berupa data primer maupun data sekunder. Sebagian dari data-data penelitian ini bersumber dari data primer yang berasal dari dokumen-dokumen pemerintahan dan organisasi internasional. Namun, mayoritas dari data yang digunakan sebagai penunjang penelitian ini berasal dari data sekunder yakni berbagai bentuk literatur seperti buku, jurnal, kumpulan artikel ilmiah, dan berita. Berbagai bentuk literatur ini didapat melalui internet dan perpustakaan. 


\section{Kesepakatan EU-JEPA dan Klausul Paris Agremeent}

Sejatinya Uni Eropa telah memasukkan isu lingkungan dalam semua kesepakatan dagang "generasi baru" yang dinegosiasikan setelah tahun 2006 (Bhardwaj, 2019). Kesepakatan dagang Uni Eropa yang pertama kali mengikutsertakan isu lingkungan dalam bab TSD telah diadopsi pada tahun 2011 dalam kerangka EU-South Korea Free Trade Agreement (Simon, 2017). Namun, arah kebijakan perdagangan Uni Eropa yang turut mengikutsertakan klausul Paris Agreement baru terimplementasikan pertama kali dalam EU-Japan Economic Partnership Agreement (EU-JEPA) yang disepakati oleh kedua belah pihak pada 17 Juli 2018 dan berlaku sejak 1 Februari 2019.

Di dalam laman Komisi Eropa disebutkan salah satu tujuan utama dari kesepakatan ini adalah "Helps us (European Union) shape global trade rules in line with our high standards and shared values" (European Commission, 2019a). Standar dan nilai di sini dapat diartikan menyangkut dengan standar dan nilai lingkungan Uni Eropa yang berdasar pada upaya pembangunan berkelanjutan dan penanggulangan perubahan iklim. Klausul kepatuhan Paris Agreement termaktub dalam bab TSD Pasal 16.4 yang berbunyi:

"The Parties recognise the importance of achieving the ultimate objective of the United Nations Framework Convention on Climate Change, done at New York on 9 May 1992 (hereinafter referred to as "UNFCCC"), in order to address the urgent threat of climate change, and the role of trade to that end. The Parties reaffirm their commitments to effectively implement the UNFCCC and the Paris Agreement, done at Paris on 12 December 2015 by the Conference of the Parties to the UNFCCC at its 21 st session. The Parties shall cooperate to promote the positive contribution of trade to the transition to low greenhouse gas emissions and climate-resilient development. The Parties commit to working together to take actions to address climate change towards achieving the ultimate objective of the UNFCCC and the purpose of the Paris Agreement." (Agreement Between the European Union and Japan for an Economic Partnership (English Version), 2018)

Selain fokus pada perubahan iklim (klausul Paris Agreement) secara khusus, EU-JEPA juga membahas tata kelola lingkungan dan perdagangan dalam konsep pembangunan berkelanjutan. Upaya pembangunan berkelanjutan diatur secara spesifik dalam bab 16 tentang TSD dan turut dimasukkan dalam bab-bab lain seperti bab Technical Barriers to Trade (bab 7) dan bab Good Regulatory Practices and Regulatory Cooperation (bab 18). Dalam bab 2 mengenai Trade in Goods juga disebutkan bahwa masing-masing pihak dapat menggunakan GATT Article $X X$ on General Exceptions yang membolehkan adanya bentuk trade measures berdasarkan tujuan perlindungan lingkungan domestik. Beberapa komitmen pembangunan berkelanjutan di antara dua 
pihak turut mencakup usaha untuk: “(1) Conserving and sustainably managing natural resources, (2) Addressing biodiversity, including combatting illegal trade in wildlife, (3) Sustainable forestry, including fighting illegal logging and (4) Sustainable fisheries, including combatting illegal, unreported and unregulated (IUU) fishing” (European Commission, 2017).

Kesepakatan asas transparansi dan akuntabilitas yang berdasar pada prinsip partisipasi masyarakat merupakan tindak lanjut dari implementasi klausul pembangunan berkelanjutan. Uni Eropa akan membentuk Domestic Advisory Group for the EU-Japan Economic Partnership Agreement, sehingga masyarakat dapat berperan aktif dalam proses implementasi perjanjian tersebut. Domestic Advisory Group tersebut berisikan anggota yang terdiri dari para serikat buruh, asosiasi pengusaha, lembaga konsumen, dan organisasi lingkungan. Selain itu, untuk menjaga konsistensi implementasi pembangunan berkelanjutan EU-JEPA termasuk mengenai klausul kepatuhan Paris Agreement, maka turut disusunlah mekanisme penyelesaian sengketa bilateral yang tersusun berjenjang dari tahap 1) Konsultasi, 2) Pembentukan panel yang berisikan para ahli independen, 3) Publikasi laporan panel, dan 4) Implementasi hasil laporan. Mekanisme penyelesaian sengketa ini turut mengaplikasikan prinsip transparansi yang mengakomodasi partisipasi masyarakat (European Commission, 2017).

\section{Kepentingan Ekonomi: Kompetitivitas Ekonomi dan Kepemimpinan di Tengah Ancaman Race to the Bottom dan Proteksionisme Global}

Seperti yang telah dijelaskan sebelumnya bahwa perspektif institusionalis hadir sebagai jembatan moderasi antara dua kutub perspektif pro-kontra yang masing-masing mendukung argumentasi mereka secara ekstrem. Namun, patut ditekankan di sini bahwa sebenarnya perspektif institusionalis secara umum mendorong proses liberalisasi perdagangan dan menolak adanya praktik-praktik proteksionisme perdagangan yang destruktif. Hal ini disebabkan menurut mereka keuntungan ekonomis secara umum dari praktik liberalisasi perdagangan bersifat konstruktif terhadap usaha perlindungan lingkungan. Selain itu, mereka beranggapan bahwa kehadiran environmental measures dalam trade agreements hanya dapat terjadi karena adanya dorongan keuntungan ekonomis yang didapat oleh para pesertanya. Keuntungan ekonomis yang didapat dari trade agreements seperti ini dipandang tidak akan merugikan lingkungan dan mendorong usaha konservasi dan perlindungannya. Motif ekonomis seperti ini ternyata turut berpengaruh pada perumusan kesepakatan EU-JEPA beserta klausul perubahan iklim di dalamnya. 
Meskipun pada umumnya perspektif institusionalis memandang bahwa globalisasi dan liberalisasi perdagangan dunia membawa benefit bagi usaha perlindungan lingkungan, ia turut menyadari dan menaruh perhatian pada dampak negatif yang kemungkinan akan timbul ke permukaan. Salah satu perhatian tersebut diarahkan pada timbulnya praktik race to the bottom diantara negara-negara. Race to the bottom adalah suatu praktik di mana negara-negara berlombalomba mengurangi standar lingkungan domestik mereka untuk mencapai keuntungan kompetitif di dalam belantara liberalisasi perdagangan internasional. Hal ini terjadi karena rasionalisasi negara-negara tersebut yang memandang bahwa standar lingkungan domestik yang lebih lemah akan berdampak pada (1) Perlindungan ekspor produk domestik di tengah kompetisi internasional dan (2) Ketertarikan MNCs yang semakin besar untuk berinvestasi di industri dalam negeri (Clark, 1995). Keuntungan-keuntungan ini akan menempatkan negara dengan standar lingkungan yang lebih rendah daripada partner dagangnya akan memiliki keuntungan kompetitif terutama dari sisi cost produksi.

Kehadiran praktik ini juga turut diperhatikan oleh negara-negara maju yang memiliki standar lingkungan domestik yang tinggi termasuk juga Uni Eropa. Apabila praktik ini menjalar luas dan menjadi sebuah fenomena global, maka selain menghambat usaha konservasi lingkungan global, hal ini juga dapat menempatkan tidak kompetitifnya posisi Uni Eropa di dalam praktik perdagangan dan investasi internasional. Produk-produk industri domestik Uni Eropa yang high cost akan dihadapkan pada situasi tidak menguntungkan di dalam pasar internasional apabila bertemu dengan produk industri negara yang tidak memiliki regulasi lingkungan yang ketat dan memiliki cost yang lebih rendah. Kehadiran kepentingan ekonomi ini turut berpengaruh pada dimasukkannya klausul-klausul lingkungan di dalam kesepakatan dagang internasional Uni Eropa termasuk dalam kasus EU-JEPA.

Adanya "intervensi" seperti ini diharapkan akan menstimulasi praktik race to the top, terkhusus terhadap partner-partner dagang yang ingin meraih benefit dari kerja sama dagang yang lebih komprehensif dengan Uni Eropa. Race to the top adalah praktik di mana negara-negara justru saling bersaing untuk meningkatkan standar lingkungannya untuk meraup keuntungan ekonomis dari proses liberalisasi ekonomi global. Praktik ini sering terjadi apabila negara-negara tersebut memiliki partner dagang yang strategis dengan standar lingkungan domestik yang ketat (Spilker et al., 2017). Adanya klausul-klausul lingkungan dan perubahan iklim dalam EU-JEPA dicanangkan akan berdampak pada semakin ketatnya regulasi lingkungan domestik di Jepang dan 
negara-negara lain yang ingin meraih akses pasar Uni Eropa yang lebih luas. Dengan adanya hal ini, maka Uni Eropa akan meraup keuntungan ekonomis sembari membawa dampak positif bagi usaha perlindungan lingkungan global.

Kehadiran EU-JEPA dengan segala norma dan nilainya turut menjadi tonggak yang mensinyalkan keinginan Uni Eropa untuk "berperan lebih" dalam konstelasi kepemimpinan ekonomi global. Keinginan ini diambil di tengah kondisi dua raksasa ekonomi dunia - Amerika Serikat dan Cina - yang justru semakin terjerembab dalam jurang perang dagang dan implementasi praktik proteksionisme. Realita seperti ini tentu membayahakan tatanan ekonomi global yang berasaskan pada prinsip perdagangan bebas dan liberalisasi ekonomi.

Uni Eropa menjadikan kerja sama perdagangan bilateral mereka dengan Jepang (dan juga dengan negara-negara lain seperti Singapura dan Vietnam) sebagai bentuk aliansi global yang memproyeksikan pengaruh mereka di luar Eropa. Strategi seperti ini dapat menjadikan Uni Eropa sebagai "pemimpin ekonomi global alternatif" di tengah proteksionismenya kebijakan dagang Amerika Serikat dan kontroversialnya kebijakan investasi BRI Cina (Valero, 2019). Tampuk kepemimpinan global ini juga menjadi ajang proyeksi nilai dan standar Uni Eropa seperti transparansi, free trade, pembangunan berkelanjutan dan perlindungan lingkungan. Oleh karena itu, dengan menjadi aktor yang semakin berpengaruh dalam percaturan ekonomi dunia, maka Uni Eropa juga akan semakin mendapatkan keuntungan ekonomis sembari terus mengekspor nilai dan norma domestik mereka ke seluruh dunia termasuk berkaitan dengan isu perubahan iklim.

\section{Kepentingan Politik Lingkungan Domestik: Proyeksi Internasional Tatanan Lingkungan Regional Uni Eropa}

Kebijakan luar negeri sebuah negara turut dipengaruhi oleh keberadaan kepentingan politik domestik dalam sebuah teori dan praktiknya. Oleh karena itu, kebijakan perdagangan Uni Eropa yang memasukkan klausul perubahan iklim juga dapat dipandang sebagai cerminan dari arah politik domestik yang terangkum dalam tata kelola lingkungan Uni Eropa. Meskipun Uni Eropa "hanya" merupakan kelompok dari beberapa negara berdaulat (alih-alih negara berdaulat), namun berkat sistem tata kelola organisasi regionalnya Uni Eropa dapat dipandang sebagai sebuah unitary actor. Peran unitary actor Uni Eropa pun khususnya sangat kentara terlihat dalam politik 
lingkungan global dimana negara-negara Eropa menaruh wewenang diplomatiknya di atas pundak Uni Eropa.

Awalnya, gagasan utama berdirinya Masyarakat Eropa (institusi pendahulu Uni Eropa) berpusat pada proses integrasi politik dan ekonomi serta harmonisasi hukum-hukum domestik diantara negara-negara Eropa. Saat itu, perumusan kebijakan lingkungan secara spesifik masih belum menjadi diskursus utama para pengambil kebijakan Eropa. Baru pada tahun 1972 Uni Eropa mulai serius memperhatikan isu lingkungan dengan diadopsinya Paris Declaration di mana para kepala negara Eropa mendeklarasikan perlunya kehadiran kebijakan lingkungan yang berjalan beriringan dengan proses ekspansi ekonomi Eropa, serta menyerukan dirumuskannya program aksi (action programme) di bidang lingkungan. Setelah deklarasi tersebut, maka Action Programme for the Environment yang pertama kali pun dirumuskan setahun setelahnya. Beberapa faktor utama di balik turning point ini diantaranya adalah terjadinya berbagai bencana alam di Eropa, yang turut menaikkan ekspektasi publik (tercermin dalam dibentuknya posisi kementerian lingkungan di negara-negara Eropa) dan semakin meningkatnya kesadaran internasional akan isu lingkungan (tercermin dalam diadakannya konferensi Stockholm tentang Lingkungan Manusia pada tahun 1972).

Meskipun formulasi kebijakan lingkungan Uni Eropa telah dimulai sejak Paris Declaration, namun baru pada tahun 1987 isu lingkungan memiliki dasar hukum (legal basis) dalam sebuah traktat Eropa. The Single European Act pada tahun 1987 memperkenalkan "Environment Title" (Title VII) yang memberikan dasar hukum pertama bagi implementasi sebuah common environment policy yang bertujuan untuk menjaga kualitas lingkungan, melindungi kesehatan manusia, dan memastikan penggunaan sumber daya alam secara rasional. Traktat-traktat Uni Eropa setelahnya seperti Treaty on European Union (1992) dan Treaty of Amsterdam (1997) turut semakin memperkuat dasar hukum penyertaan isu lingkungan ke dalam kerangka kebijakan Uni Eropa. Disahkannya Treaty on the Functioning of the European Union/Treaty of Lisbon (2007) semakin membuat cakupan kebijakan lingkungan Uni Eropa semakin luas dengan dimasukkannya tujuan "memerangi perubahan iklim" menjadi salah satu tujuan khusus Uni Eropa seperti halnya dimasukkannya konteks pembangunan berkelanjutan dalam perumusan pola hubungan Uni Eropa dengan negara lain (European Parliament, 2019).

Saat ini, kebijakan lingkungan Uni Eropa telah sangat luas mencakup berbagai bidang dan isu, mulai dari yang dasar seperti kualitas air dan udara, pengaturan limbah, pengurangan pestisida 
dan konservasi alam, hingga yang cukup kompleks seperti regulasi produk rekayasa genetika, perencanaan tata kota yang berkelanjutan dan pemanasan global. Guna mengatasi isu-isu tersebut kebijakan lingkungan Uni Eropa didasarkan pada prinsip-prinsip, beberapa di antaranya bersifat cukup umum (polluter pays, rectifying pollution at source), sementara prinsip lainnya bersifat lebih spesifik yang turut mencerminkan besarnya ambisi Uni Eropa (precaution, sustainable development) (Mathis, 2016). Selain itu, kebijakan lingkungan Uni Eropa juga ditunjang oleh prinsip umum Uni Eropa yang mengarahkan proses integrasi permasalahan lingkungan ke dalam berbagai bidang kebijakan Uni Eropa. Maka bukan menjadi suatu keheranan apabila kebijakan Uni Eropa di luar bidang lingkungan (seperti kebijakan energi) juga mengikutsertakan permasalahan lingkungan di dalamnya.

Berkaitan dengan tata kelola lingkungan Uni Eropa, menurut Clapp (2014), Uni Eropa secara luas dipandang sebagai sebuah contoh suksesnya sebuah organisasi regional dalam memadukan antara proyek harmonisasi regulasi regional di bidang lingkungan dengan proses integrasi ekonomi kawasan. Isu lingkungan dipandang merupakan sebuah kesatuan tak terpisahkan dari kebijakan perdagangan dan ekonomi Uni Eropa. Di samping usaha integrasi, kebijakan lingkungan Uni Eropa juga berpusat pada partisipasi mereka di dalam kerja sama lingkungan internasional. Uni Eropa telah menjadi party di dalam berbagai kesepakatan lingkungan internasional dan turut aktif berkontribusi terhadap tercapainya kesepakatan tentang strategi global termasuk Paris Agreement on Climate Change pada tahun 2015.

Pola kebijakan ketat Uni Eropa mengenai lingkungan ini berakibat pada diturutsertakannya pula isu-isu lingkungan (termasuk perubahan iklim) ke dalam kesepakatan-kesepakatan dagang termasuk dalam kasus EU-JEPA. Hal ini terjadi karena secara rasional negara-negara yang memiliki regulasi lingkungan domestik yang ketat pada umumnya tidak merasakan beban yang berat saat menyebarkan standar-standar mereka secara global. Beberapa penelitian terakhir juga turut memperkuat argumen ini dimana dijelaskan bahwa komitmen Uni Eropa dan Amerika Serikat untuk menyertakan klausul lingkungan ke dalam kesepakatan dagang masing-masing ternyata turut dipengaruhi oleh keinginan untuk menyebarkan norma-norma lingkungan domestik mereka secara internasional (Morin et al., 2018). 


\section{Kepentingan Diplomasi Lingkungan: Memperkuat Efektivitas dan Eksistensi Rezim Perubahan Iklim Paris Agreement}

Perspektif institusionalis telah memberikan analisis tentang bagaimana sebenarnya bentuk hubungan antara perdagangan dan lingkungan. Perspektif ini memandang bahwa hubungan politik diantara keduanya dapat bersifat positif dimana kerja sama perdagangan dapat menjadi platform konkret bagi terciptanya usaha penanggulangan masalah lingkungan, termasuk isu perubahan iklim pada saat rezim lingkungan global menghadapi tantangan terhadap legitimasi dan efektivitasnya. Hal ini dikarenakan kerja sama perdagangan sering kali memberikan insentif yang bernilai seperti akses pasar dan bebas bea dibandingkan dengan MEAs yang sering kali memberikan burden cost dan keuntungan lingkungan yang tidak jelas terlihat. Selain itu, kehadiran klausul-klausul lingkungan di dalam kerja sama perdagangan juga dapat membantu implementasi norma-norma tersebut di saat banyak kehadiran MEAs yang lemah dan cenderung unenforceable (Coyler, 2004). Oleh karena itu, perspektif institusionalis memberikan framework prognostic berupa dimasukkannya klausul environmental measures di dalam trade agreements. Argumentasi seperti ini dapat dilihat turut mendasari dimasukkannya klausul Paris Agreement di dalam kesepakatan EU-JEPA. Meskipun demikian, perspektif institusionalis masih menekankan pentingnya keberadaan tata kelola internasional sebagai ujung tombak dalam menghadapi kemungkinan dampak negatif dari liberalisasi perdagangan dunia saat ini (Vogler, 2014).

Selain mendapatkan pengaruh dari arah politik kawasan yang fokus terhadap permasalahan lingkungan, kebijakan internasional Uni Eropa juga dipengaruhi oleh keberadaan rezim lingkungan internasional. Di samping menjadi motor penunjang tata kelola lingkungan regional, rezim lingkungan internasional juga turut menjadi salah satu lahan kepemimpinan diplomatik global Uni Eropa. Oleh karena itu, kebijakan perdagangan Uni Eropa yang memasukkan klausul perubahan iklim juga dapat dirasionalisasikan sebagai representasi usaha Uni Eropa sebagai salah satu pemimpin rezim lingkungan global untuk "berbuat lebih" dalam usaha untuk menerapkan Paris Agreement sembari menjaga komitmen global terhadap kesepakatan tersebut.

Paris Agreement merupakan kesepakatan internasional di bawah UNFCC yang tercapai saat diadakannya COP 21 di Paris pada tahun 2015. Salah satu fitur utama dari kesepakatan ini adalah kewajiban bagi semua party untuk masing-masing menentukan nationally determined contributions (NDCs) mereka dan untuk selalu meningkatkan upaya dan target mereka setiap lima tahun sekali. Paris Agreement juga mensyaratkan adanya laporan secara teratur dari semua party 
tentang emisi dan tentang upaya implementasi NDCs mereka (United Nations Framework Convention on Climate Change, 2019).

Semenjak proses negosiasi Paris Agreement, Uni Eropa telah berkontribusi dalam membangun koalisi yang luas antara negara maju dengan negara berkembang demi tercapainya sebuah kesepakatan internasional. Strategi bridge-building Uni Eropa dalam kesepakatan lingkungan internasional adalah menobatkan peranan Uni Eropa sebagai "leaditor" atau "leadercum-mediator" (Bäckstrand \& Elgström, 2013). Selain berperan dalam proses negosiasi, Uni Eropa juga menunjukkan kesungguhan komitmen mereka dalam berpartisipasi di dalam Paris Agreement. Uni Eropa secara formal meratifikasinya pada tanggal 5 Oktober 2016 yang dengan sendirinya menjadikan Paris Agreement berlaku (entry into force) pada 4 November 2016. Berdasarkan kerangka Paris Agreement Uni Eropa menetapkan target NDCs mereka yakni untuk mengurangi tingkat emisi gas rumah kaca pada tahun 2030 setidaknya 40\% lebih rendah apabila dibandingkan dengan tahun 1990. Semua produk legislasi yang berkaitan dengan implementasi target ini telah diadopsi oleh Uni Eropa pada akhir tahun 2018 (European Commission, 2019b).

Eksistensi Paris Agreement yang baru seumur jagung langsung terancam tatkala pada tanggal 1 Juni 2017 Presiden Amerika Serikat Donald Trump mengumumkan bahwa pemerintahannya akan keluar dari Paris Agreement. Pengumuman ini merupakan bentuk realisasi janji kampanye Presiden Trump sebelumnya di mana ia berjanji akan mengeluarkan Amerika Serikat dari Paris Agreement. Presiden Trump memandang bahwa substansi Paris Agreement bersifat tidak adil terhadap Amerika Serikat dan akan menempatkan secara permanen ekonomi negara tersebut dalam posisi tidak menguntungkan (Chakraborty, 2017). Keputusan Presiden Trump ini lantas disambut oleh reaksi negatif internasional yang menyesalkan dan mengkritik keluarnya Amerika Serikat dalam tata kelola perubahan iklim internasional termasuk Uni Eropa. Selain menghambat pencapaian target global yang dicanangkan dalam Paris Agreement (dikarenakan posisi Amerika Serikat sebagai negara polluter terbesar kedua di dunia), keluarnya Amerika Serikat juga dikhawatirkan akan memunculkan kemunduran komitmen nasional negaranegara lain terhadap ambisi Paris Agreement (Herz, 2018).

Mundurnya Amerika Serikat dari Paris Agreement lantas disikapi dengan aktif oleh Uni Eropa. Uni Eropa lantas langsung mencari aliansi dengan China untuk mengambil peran sebagai pemimpin dunia dalam usaha mengatasi perubahan iklim. Komisioner Iklim Uni Eropa Miguel Arias Cañete menyatakan bahwa "The EU and China are joining forces to forge ahead on the 
implementation of the Paris Agreement and accelerate the global transition to clean energy" (Boffey \& Neslen, 2017). Komitmen bersama ini disikapi sebagai salah satu respons reaktif Uni Eropa untuk "menyelamatkan" Paris Agreement dibalik bayang-bayang usaha penggembosannya oleh Amerika Serikat.

Perkembangan diskursus perubahan iklim di level internasional yang terancam oleh mundurnya Amerika Serikat, turut berdampak pada perubahan fokus kebijakan dagang Uni Eropa. Selain dipengaruhi oleh tata kelola lingkungan regional, Uni Eropa mulai memandang urgensi kehadiran klausul perubahan iklim dalam kesepakatan dagang internasional sebagai salah satu jalan unilateral untuk menyelamatkan Paris Agreement. Concern akan hal ini mulai terlihat dari arah evaluasi internal Uni Eropa yang dimotori oleh otoritas Perancis yang menilai bahwa kesepakatan dagang Uni Eropa dengan Kanada, yakni Comprehensive Economic and Trade Agreement, tidak sesuai dengan usaha untuk mengatasi perubahan iklim. Berbekal evaluasi ini Perancis mendorong "Compliance with the Paris Agreement among the essential element clauses of the political dialogue and cooperation agreements that are decided along with trade agreements" (Dupré \& Leré, 2018).

Pandangan Perancis ini disikapi secara positif oleh Uni Eropa di mana Komisioner Perdagangan Uni Eropa Cecilia Malmström menyatakan bahwa referensi Paris Agreement merupakan suatu hal yang dibutuhkan dalam kesepakatan dagang Uni Eropa hari ini (Stone, 2018). Perancis melalui pejabatnya, Jean-Baptiste Lemoyne turut menyerukan "No Paris Agreement, no trade agreement. The US knows what to expect" sebagai reaksi atas pendirian negatif Amerika Serikat terhadap upaya global dalam mengatasi perubahan iklim (Dupré \& Leré, 2018). Arah kebijakan kerja sama perdagangan internasional inilah yang akhirnya dapat diimplementasikan pertama kali dalam bentuk kehadiran klausul Paris Agreement di dalam kesepakatan dagang EUJEPA.

\section{Simpulan}

Uni Eropa memiliki arah kebijakan perdagangan internasional baru tatkala mereka mensyaratkan klausul kepatuhan Paris Agreement sebagai salah satu prasyarat bagi negara lain yang ingin mengadakan perjanjian dagang bilateral mereka. Implementasi awal dari kebijakan ini terwujud dalam disepakatinya kesepakatan EU-JEPA antara Uni Eropa dan Jepang. Kesepakatan ini 
memuat klausul kepatuhan Paris Agreement dan pengambilan langkah konkret dalam memerangi pemanasan global.

Berdasarkan analisis yang diajukan oleh perspektif institusionalis maka dapat ditarik proposisi bahwa kebijakan Uni Eropa tersebut didasari oleh adanya potensi untuk meraup dampak berimbang yang bernilai positif baik dalam usaha pengembangan kesejahteraan ekonomi maupun perlindungan lingkungan. Rasionalisasi ini terepresentasi dalam bentuk kepentingan ekonomis dan kepentingan politik lingkungan domestik. Kepentingan ekonomis di sini berupa peningkatan kompetitivitas domestik dan proyeksi kepemimpinan global alternatif. Adapun kepentingan politik lingkungan domestik di sini berupa terealisasikannya norma dan prinsip kebijakan lingkungan regional Uni Eropa di tingkat internasional.

Namun di samping itu, kebijakan Uni Eropa tersebut juga memiliki rasionalisasi tambahan berupa kepentingan untuk menjaga keberlangsungan tata kelola lingkungan. Uni Eropa memasukkan klausul kepatuhan Paris Agreement ke dalam prasyarat FTA-nya (termasuk EUJEPA) sebagai cara untuk meningkatkan kepatuhan rezim lingkungan melalui kekuatan enforcement yang ditawarkan oleh FTA tersebut. Hal ini ternyata turut disebabkan oleh realita keluarnya AS dari rezim Paris Agreement yang menghadirkan ancaman besar terhadap keberlangsungan rezim perubahan iklim tersebut.

\section{Daftar Pustaka}

Agreement Between the European Union and Japan for an Economic Partnership (English Version). (2018). Diambil dari https://trade.ec.europa.eu/doclib/docs/2018/august/tradoc_157228.pdf

Bäckstrand, K., \& Elgström, O. (2013). The EU's role in climate change negotiations: From leader to "leadiator." Journal of European Public Policy, 20(10).

Becker, S. (2019). Leveraging Trade Agreements to Reduce Greenhouse Gas Emissions in Accordance with the Paris Agreement [Claremont McKenna College]. Diambil dari https://scholarship.claremont.edu/cgi/viewcontent.cgi?article $=3293 \&$ context=cmc theses

Benedick, R. E. (1998). Diplomacy for the Environment. Environmental Diplomacy, 3-12. Diambil dari https://www.aicgs.org/site/wpcontent/uploads/2011/11/environmentaldiplomacy.pdf

Bhardwaj, A. (2019). The Trade-Environment Linkage in the EU-Japan Economic Partnership Agreement. EU Trade and Investment Policy (EU-TIP). Diambil dari https://more.bham.ac.uk/eutip/the-trade-environment-linkage-in-the-eu-japan-economicpartnership-agreement/

Boffey, D., \& Neslen, A. (2017). China and EU strengthen promise to Paris deal with US poised to step away. The Guardian. Diambil dari 
https://www.theguardian.com/environment/2017/may/31/china-eu-climate-lead-parisagreement

Chakraborty, B. (2017). Paris Agreement on climate change: US withdraws as Trump calls it "unfair.” Fox News. Diambil dari_https://www.foxnews.com/politics/paris-agreement-onclimate-change-us-withdraws-as-trump-calls-it-unfair

Clapp, J. (2014). International Political Economy and the Environment. In M. Betsill, K. Hochstetler, \& D. Stevis (Ed.), Advances in International Environmental Politics (2 ed., hal. 107-136). Palgrave Macmillan.

Clapp, J., \& Dauvergne, P. (2005). Paths to a Green World: The Political Economy of the Global Environment. MIT Press.

Clark, G. L. (1995). Global Competition and Environmental Regulation: Is the 'Race to the Bottom' Inevitable? In R. Eckersley (Ed.), Markets, the State and the Environment (hal. 229257). Palgrave.

Condon, M. (2015). The Integration of Environmental Law into International Investment Treaties and Trade Agreements: Negotiation Process and the Legalization of Commitments. Virginia Environmental Law Journal, 33(1), 102-152.

Coyler, D. (2004). Environmental Provisions in Trade Agreements. Diambil dari https://core.ac.uk/download/pdf/7055451.pdf

Dupré, M., \& Leré, S. (2018). Trade and climate: How the EU can protect the Paris Agreement. Euractiv. Diambil dari https://www.euractiv.com/section/climateenvironment/opinion/trade-and-climate-how-the-eu-can-protect-the-paris-agreement/

European Commission. (2017). An Introduction to the EU-Japan Economic Partnership Agreement: Sustainable development. Diambil dari https://trade.ec.europa.eu/doclib/docs/2017/july/tradoc_155721.pdf

European Commission. (2019a). In Focus: EU-Japan Economic Partnership Agreement. Diambil dari https://ec.europa.eu/trade/policy/in-focus/eu-japan-economic-partnership-agreement/

European Commission. (2019b). Paris Agreement. EU Climate Action. Diambil dari https://ec.europa.eu/clima/policies/international/negotiations/paris_en\#tab-0-0

European Parliament. (2019). Environment Policy: General Principles and Basic Framework. Diambil dari https://www.europarl.europa.eu/factsheets/en/sheet/71/environment-policygeneral-principles-and-basic-framework

Foramitti, M. C. (2019). Is The Future of EU Trade Green?: Trade and Sustainable Development Chapters in the EU's Free Trade Agreements in Asia [University of Gothenburg]. Diambil dari https://gupea.ub.gu.se/bitstream/2077/61788/1/gupea_2077_61788_1.pdf

Herz, S. (2018). Climate action should be a condition for future EU trade deals. Euractiv. Diambil dari https://www.euractiv.com/section/climate-environment/opinion/climate-action-shouldbe-a-condition-for-future-eu-trade-deals/

Jinnah, S. (2011). Strategic Linkages: The Evolving Role of Trade Agreements in Global Environmental Governance. Journal of Environment \& Development, 20(2), 191-215.

Kolari, T. (2002). Promoting Compliance with International Environmental Agreements - An Interdisciplinary Approach with Special Focus on Sanctions [University of Joensuu]. Diambil dari https://www.peacepalacelibrary.nl/ebooks/files/C08-0029-KolariPromoting.pdf

Mathis, C.-F. (2016). European environmental policy. Encyclopédie pour une histoire nouvelle de l'Europe (EHNE). Diambil dari https://ehne.fr/en/article/political-epistemology/europeanmodel-defined-public-policies/european-environmental-policy 
Milewicz, K., Hollway, J., Peacock, C., \& Snidal, D. (2018). Beyond Trade: The Expanding Scope of the Nontrade Agenda in Trade Agreements. Journal of Conflict Resolution.

Moltke, K. von. (2002). Trade and the Environment: The linkages and the politics. https://www.iisd.org/sites/default/files/publications/canberra.pdf

Morin, J. F., Dür, A., \& Lechner, L. (2018). Mapping the Trade and Environment Nexus: Insights from a New Data Set. Global Environmental Politics, 18(1), 122-139.

Morin, J. F., \& Jinnah, S. (2018). The Untapped Potential of Preferential Trade Agreements for Climate Governance. Environmental Politics.

Nakanishi, Y. (2020). Climate Change and Environmental Issues in the Economic Partnership Agreement and the Strategic Partnership Agreement between the European Union and Japan. Hitotsubashi Journal of Law and Politics, 48, 9-21.

Olper, A. (2016). The political economy of trade-related regulatory policy: Environment and global value chain. Bio-based and Applied Economics, 5(3), 287-324.

Pisupati, B. (2015). South-South Cooperation and Environmental Diplomacy: Options for India (No. 2). Diambil dari http://fledgein.org/wp-content/uploads/2017/11/EnvironmentalDiplomacy.pdf

Simon, F. (2017). Calls grow for 'green clause' in EU trade deals. Euractiv. Diambil dari https://www.euractiv.com/section/energy-environment/news/calls-grow-for-green-clausein-eu-trade-deals/

Spilker, G., Koubi, V., \& Bernauer, T. (2017). International Political Economy and the Environment. In Oxford Research Encyclopedia Politics. Oxford University Press USA. Diambil dari https://doi.org/10.1093/acrefore/9780190228637.013.172

Stevis, D. (2014). The Trajectory of International Environmental Politics. In M. Betsill, K. Hochstetler, \& D. Stevis (Ed.), Advances in International Environmental Politics (2 ed., hal. 13-44). Palgrave Macmillan.

Stone, J. (2018). EU to refuse to sign trade deals with countries that don't ratify Paris climate change accord. The Independent. Diambil dari https://www.independent.co.uk/news/world/europe/eu-trade-deal-paris-climate-changeaccord-agreement-cecilia-malmstr-m-a8206806.html

United Nations Framework Convention on Climate Change. (2019). The Paris Agreement. Diambil dari https://unfccc.int/process-and-meetings/the-paris-agreement/the-parisagreement

Valero, J. (2019). EU and Japan join forces to counter US and Chinese initiatives. Euractiv. Diambil dari https://www.euractiv.com/section/eu-china/news/eu-and-japan-join-forces-tocounter-us-and-chinese-initiatives/

Vogler, J. (2014). Environmental Issues. In J. Baylis, S. Smith, \& P. Owens (Ed.), The Globalization of World Politics: An Introduction to International Relations (6 ed., hal. 341356). Oxford University Press.

Werksman, J., \& Buri, I. (2019). European Union Trade and Climate Change Policy: Pursuing a "Cooperative Approach" to Promoting the Implementation of the Paris Agreement. Yale Center for Environmental Law \& Policy. Diambil dari https://envirocenter.yale.edu/sites/default/files/files/CoolHeads_Werksman(1).pdf

World Bank. (2019a). Exports of goods and services (current US\$) - World. World Bank Open Data. Diambil dari https://data.worldbank.org/indicator/NE.EXP.GNFS.CD?year_high_desc=true\&locations $=1$ $\underline{\mathrm{W}}$ 
World Bank. (2019b). GDP (current US\$) - World. World Bank Open Data. Diambil dari https://data.worldbank.org/indicator/NY.GDP.MKTP.CD?year_high_desc=true\&locations= $1 \mathrm{~W}$

World Bank. (2019c). Trade (\% of GDP) - World. World Bank Open Data. Diambil dari https://data.worldbank.org/indicator/NE.TRD.GNFS.ZS?locations=1W 